\title{
Waste water as a Photoelectrochemical Fuel Source for Biphasic Batteries using Liquid Crystals
}

\author{
Amal A. Altalhi* \\ Chemistry department, Faculty of science, Taif University, KSA \\ *Corresponding author
}

A B S T R A C T

\section{Keywords \\ Liquid crystals, $\mathrm{N}-$ methyl phenothiazine, Photogalvanic cell Fill factor, Power conversion efficiency, Photocurrent, Photopotential \\ Article Info \\ Accepted: \\ 16 November 2020 \\ Available Online: \\ 10 December 2020}

The power conversions was studied by producing a voltage-current plot for each system using $\mathrm{N}$-methyl phenothiazine as an active photoagent prepared in the L $\alpha$ phase of the crystalline liquid. The photopotential, photocurrent and power were generated by the photogalvanic cell, the conversion efficiency of cell was determined as $27.305 \%$. A mechanism was proposed for the power production process using industrial run-off or other waste water supplies as electrochemical remediation power sources for waste water management which environmentally friendly and little cost to operate.

\section{Introduction}

Photogalvanic cells ${ }^{1}$ work by creating high energy products where, the product is excited by a photon; the products, full of energy, release this electrochemically in the form of electricity a concentration change in the two form of redox couple allows the cell to develop a photovoltage.

However, a self-assembles lyotropic liquid crystals $^{2,3}$ was used to produce biphasic photogalvainc cells 'liquid crystal|liquid'4, study and optimize a series of photogalvanic cells in order to achieve the highest power conversion as well as study the mechanism for power production within the cell. Photogalvanic $^{5}$ and photochemistry ${ }^{6}$ in general are well studied.

This study will try to produce a novel system and show how cells can be created using 
water waste with very little cost to operate and environmentally friendly.

Materials and Methods

\section{Electrochemical measurements}

The electrochemical measurements were recorded using an Autolab PGSTAT30 potentiostat. In all cases, a three electrode system was employed, with nickel wire wound into a spiral serving as the counter electrode, and a silver/silver chloride was utilized as the reference electrode. The working electrode was a $3.0 \mathrm{~mm}$ diameter glassy carbon disc electrode ( purchased from BASI,UK).

\section{Reagents}

Allchemical reagents were purchased from Sigma-Aldrich.

\section{Procedures}

\section{Formulation of normal lyotropic liquid crystals}

Surfactant (Brij 35 or Triton $\mathrm{X}$ $100)^{7,8}$ /aqueous electrolyte $(\mathrm{KCl})$ mixtures in the mass ratio required by the published phase diagrams were homogenised in the presence of the required amount of redox dopant and photosensitizers N-methylphenothiazine $(\mathrm{NMP})^{9}$ through heating, to approximately $320 \mathrm{~K}$, with stirring, so as to form the micellar isotropic phase, for about one hour. The samples were then allowed to cool, slowly to $294 \pm 2 \mathrm{~K}$.

\section{System under investigation (Photo-biphasic batteries)}

An indium tin oxide (ITO) cell was attached with tube then half filled it with then half filled with the NMP liquid crystal and the aqueous $\mathrm{ZnCl}_{2}$ solution was then added on top of it ${ }^{10}$. It was decided that a two phases, liquid crystal |liquid photogalvanic cell should be constructed and tested. The photoactive agent NMP was suggested for study and so several experiments were planned using this thionine like chemicals. This was suggested as its likeness to thionine as well as it never being studied for photocells before. Chloroform ${ }^{11}$ was proposed as a mediator as it would act as an artificial pollutant.

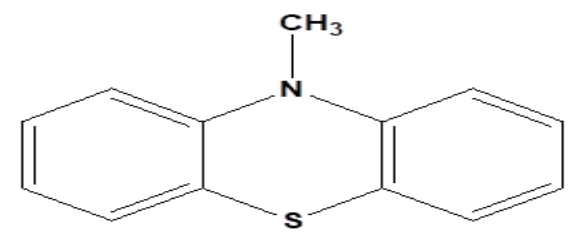

N-methylphenothiazine

\section{Results and Discussion}

UV-Vis spectra of NMP in $L_{\alpha}$ phase and H1phase

The experimentally observed absorption for NMP maxima is $\pi$ to $\pi^{*}$ peak at $352 \mathrm{~nm}(3.52$ $\mathrm{eV}$ ) in $\mathrm{L} \alpha 2.6628$ and in $\mathrm{H}_{1}$ phase the absorbance is 2.2190 (Figure 1). So it can be seen that the L $\alpha$ phase observed higher absorbance than $\mathrm{H}_{1}$. However, the energy band was calculated from the wavelength by using this formula ${ }^{12-14}$ :Energy $(\mathrm{E})=\frac{\boldsymbol{h} \times \boldsymbol{c}}{\lambda}$, where, Energy $(\mathrm{E})=$ band gap, planks constant $(\mathrm{h})=6.626 \times 10^{\wedge} \wedge^{34}$ Joules $\mathrm{sec}$, velocity of light $(\mathrm{C})=2.99 \times 10^{\wedge}{ }^{8}$ meter $/ \mathrm{sec}$ and wavelength $(\lambda)=$ absorption peak value. Also $1 \mathrm{eV}=1.6 \times 10^{\wedge-19}$ Joules (conversion factor).

\section{Determination of NMP by differential pulse voltammetry (DPV)}

The DPV ${ }^{15}$ exhibited anodic peak in about $0.523 \mathrm{~V}$ to the oxidation of NMP in $\mathrm{L}_{\alpha}$ phase (Figure 2), also exhibited anodic peak in about $0.5532 \mathrm{~V}$ to the oxidation of NMP in $\mathrm{H}_{1}$ phase (Figure 3). Surfactant changes the potential peak NMP and therefore the 
charging current. The peak potential at $\mathrm{L}_{\alpha}$ phase has lower than at $\mathrm{H}_{1}$ phase. The height of the current wave of NMP in L $\alpha$ phase was found to be higher than in $\mathrm{H}_{1}$ phase. Therefore, the $\mathrm{L}_{\alpha}$ phase was chosen for use in design of photogalvanic cell.

Effect of variation of NMP concentration: $\mathrm{Zn}\left|\mathrm{Zn}^{2+}, \mathbf{C H C l}_{3}, \mathbf{N M P}\right|$ ITO

All cells measured in the same conditions (light intensity $=103.2 \mu \mathrm{W} / \mathrm{cm}^{2} /$ electrode area $=0.78 \mathrm{~cm}^{2} / \mathrm{ZnCl}_{2}=0.01 \mathrm{M}$ ). As we can see from Table 1 increasing in the concentration of NMP there is increasing in the electrical output until reach the maximum point and then decrease.

On the lower concentration range of NMP; there is a limited number of photosensitized molecules to absorb the major portion of the light and therefore, a few number of electrons can reach the zinc electrode and a low electrical output was obtained. Table 2 shows the calculation of max power density, fill factor and power conversion efficiency for each cell.

Table.1 Effect of variation of photosensitizer NMP concentration

\begin{tabular}{|r|l|l|l|l|l|}
\hline NMP concentration & $\mathbf{0 . 0 1} \mathbf{M}$ & $\mathbf{0 . 1} \mathbf{M}$ & $\mathbf{1} \mathbf{M}$ & $\mathbf{1 . 7 5} \mathbf{M}$ & $\mathbf{2} \mathbf{M}$ \\
\hline Photopotential $(\mathbf{V})$ & 0.481 & 0.803 & 0.792 & 0.850 & 0.550 \\
\hline Photocurrent $(\boldsymbol{\mu A})$ & 14.1815 & 14.872 & 27.647 & 14.705 & 10.41 \\
\hline Power $(\boldsymbol{\mu W})$ & 6.8210 & 11.9420 & 21.89 & 12.499 & 5.73 \\
\hline
\end{tabular}

Table.2 Calculation of max power density, fill factor and power conversion efficiency for each cell (NMP)

\begin{tabular}{|l|c|c|c|}
\hline $\begin{array}{c}\text { NMP } \\
\text { concentration }\end{array}$ & Max Power Density & $\begin{array}{c}\text { Fill } \\
\text { Factor }\end{array}$ & $\begin{array}{c}\text { Power Conversion } \\
\text { efficiency }\end{array}$ \\
\hline $\mathbf{0 . 0 1} \mathbf{M}$ & $8.743 \mu \mathrm{W} / \mathrm{Cm}^{2}$ & 0.226 & $8.472 \%$ \\
\hline $\mathbf{0 . 1} \mathbf{M}$ & $15.3102 \mu \mathrm{W} / \mathrm{Cm}^{2}$ & 0.256 & $14.835 \%$ \\
\hline $\mathbf{1 ~ M}$ & $\mathbf{2 8 . 1 7} \boldsymbol{\mu} \mathrm{W} / \mathrm{Cm}^{2}$ & $\mathbf{0 . 2 4 2}$ & $\mathbf{2 7 . 3 0 5 \%}$ \\
\hline $\mathbf{1 . 7 5} \mathbf{M}$ & $16.012 \mu \mathrm{W} / \mathrm{Cm}^{2}$ & 0.245 & $15.516 \%$ \\
\hline $\mathbf{2} \mathbf{M}$ & $7.346 \mu \mathrm{W} / \mathrm{Cm}^{2}$ & 0.224 & $7.118 \%$ \\
\hline
\end{tabular}

Table.3 Calculation of max power density, fill factor and power conversion efficiency for each cell $\left(\mathrm{ZnCl}_{2}\right)$

\begin{tabular}{|c|c|c|c|}
\hline $\mathbf{Z n C l}_{2}$ concentration & $\begin{array}{c}\text { Max Power } \\
\text { Density }\end{array}$ & $\begin{array}{c}\text { Fill } \\
\text { Factor }\end{array}$ & $\begin{array}{c}\text { Power Conversion } \\
\text { efficiency }\end{array}$ \\
\hline $\mathbf{0 . 0 0 4} \mathbf{M}$ & $2.4410 \mu \mathrm{W} / \mathrm{Cm}^{2}$ & 0.2419 & $2.3653 \%$ \\
\hline $\mathbf{0 . 0 0 8} \mathbf{M}$ & $4.4789 \mu \mathrm{W} / \mathrm{Cm}^{2}$ & 0.2507 & $4.3400 \%$ \\
\hline $\mathbf{0 . 0 1} \mathbf{M}$ & $\mathbf{2 8 . 1 7} \boldsymbol{\mu W} / \mathrm{Cm}^{2}$ & $\mathbf{0 . 2 4 2}$ & $\mathbf{2 7 . 3 0 5 \%}$ \\
\hline $\mathbf{0 . 0 1 6} \mathbf{M}$ & $3.4600 \mu \mathrm{W} / \mathrm{Cm}^{2}$ & 0.2546 & $3.353 \%$ \\
\hline $\mathbf{0 . 0 1 9} \mathbf{M}$ & $2.2208 \mu \mathrm{W} / \mathrm{Cm}^{2}$ & 0.2428 & $2.15203 \%$ \\
\hline
\end{tabular}


Fig.1 UV-Vis spectra of 0.1 M NMP in L $\alpha$ phase and $\mathrm{H}_{1}$ phase

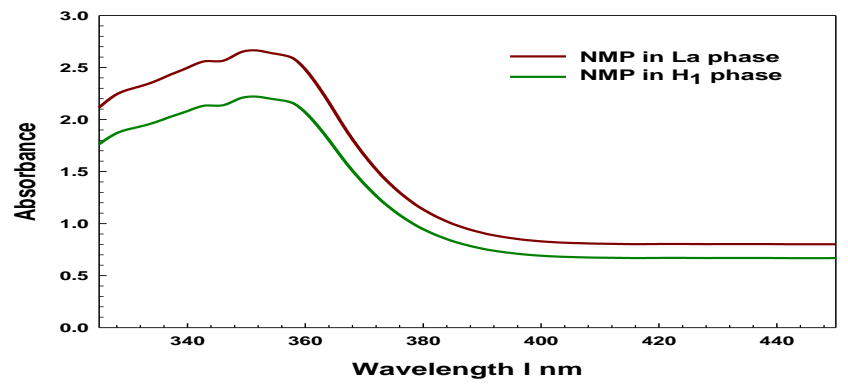

Fig.2 Differential pulse voltammograms of 0.1M of NMP, in L $\alpha$ phase, with scan rate $0.05 \mathrm{~V} / \mathrm{s}$

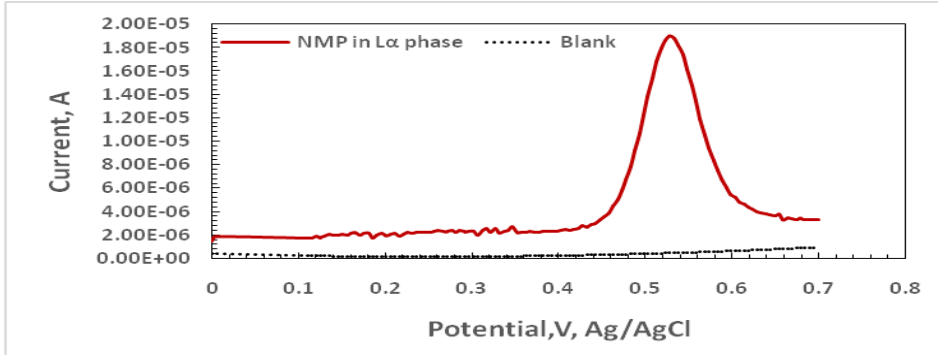

Fig.3 Differential pulse voltammograms of $0.1 \mathrm{M}$ of NMP, in $\mathrm{H}_{1}$ phase, with scan rate $0.05 \mathrm{~V} / \mathrm{s}$

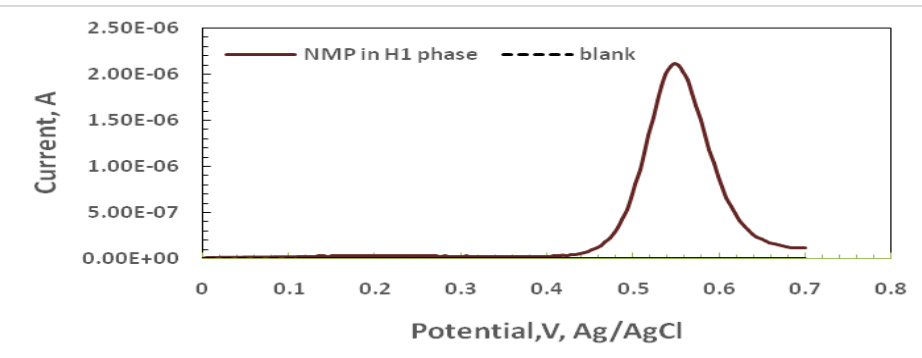

Fig.4 Effect of variation of $\mathrm{ZnCl}_{2}$ concentrations on electrical output

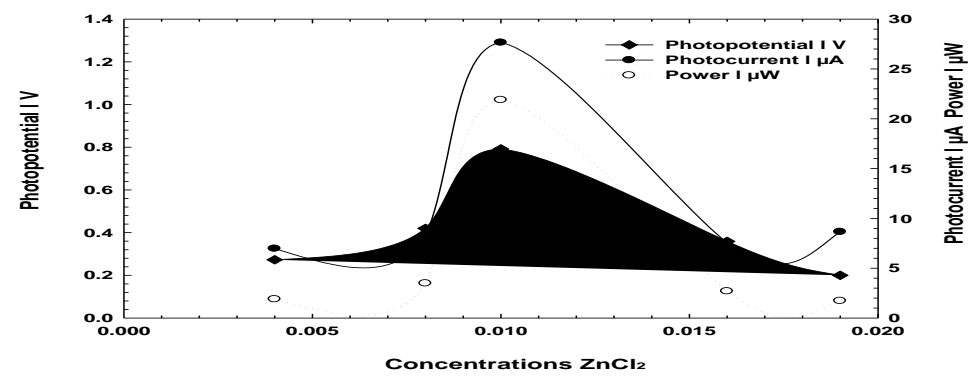


Fig.5 Current-voltage (i-v) curve of the cell $\left(\mathrm{L}_{\alpha}, \mathrm{H}_{1}\right)$

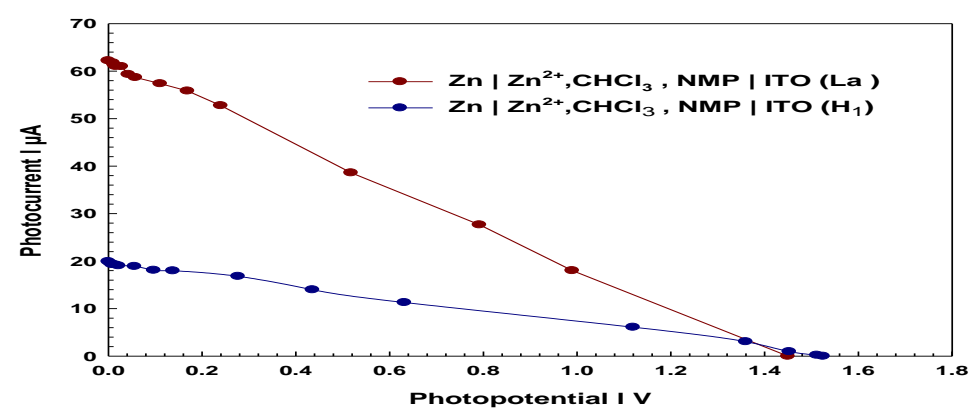

Effect of variation of reductant $\left(\mathrm{ZnCl}_{2}\right)$ concentration

With the increase in concentration of the reductant the photopotential and photocurrent were found to increase until they reach a maximum value. On further increase in concentration of reductant the decrease in electrical output of The cell was found. graphically the $\mathrm{NMP}-\mathrm{ZnCl}_{2}$ system represented graphically in Figure 4, however, table 3 shows the calculation of max power density, fill factor and power conversion efficiency for each cell.

\section{Possible reaction mechanism}

Using the analogues reaction ${ }^{16-18}$ outlined in the introduction section of this document by Girault a reaction mechanism can be postulated.

\section{In the liquid crystal phase}

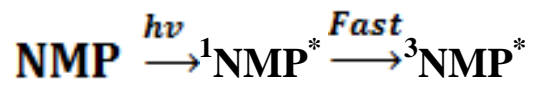

${ }^{3} \mathrm{NMP}^{*}+\mathrm{CHCl}_{3} \rightarrow \mathrm{Cl}^{-}+\mathrm{CHCl}_{2}+\mathrm{NMP}^{+}$

Where ${ }^{1} \mathrm{NMP}^{*}$ is the excited singlet state and ${ }^{3} \mathrm{NMP}^{*}$ is the excited triplet state.

\section{At the light electrode}

$\mathrm{NMP}^{+\cdot}+\mathbf{e}^{-} \rightarrow \mathrm{NMP}$

At dark electrode

$\frac{1}{2} \mathbf{Z n}-\mathbf{e}^{-} \rightarrow \frac{1}{2} \mathbf{Z n}^{2+}$

This shows how NMP can be used as the light harvester and the zinc electrode is sacrificial. The excited singlet state is the most likely to be produced on direct excitation however it will quickly relax into the less excited triplet state.

\section{The effect of surfactant in PC}

The use of Triton- $X$ as a replacement to Brij35 to see the effect of liquid crystal phases on the PC. From UV-Vis spectroscopy and DPV we can see the low absorbance and electrochemical properties this is probably due to the arrangement ${ }^{19}$ of molecules in $\mathrm{H}_{1}$ phase it causes a lot of refraction and less absorbance than $\mathrm{L}_{\alpha}$ phase of light. It can be seen Figure 5 is not an ideal situation as a lamellar phase with $8.864 \%$ PC.

In conclusion this work has demonstrated that a photogalvanic cell can be constructed that can have high conversion rates, $\approx 27.305 \%$. Although the reaction mechanisms given cannot be fully verified it does seem to fit the empirical evidence. Namely that the stepwise reaction is far less efficient than the concerted, faster reaction. The ability for 
power to be produced even when very little chloroform is present is a property that makes this type of cell of interest. A novel attempt at power production was attempted with the construction and optimization of a photogalvanic cell system. The study aimed to create a cell that could be produced using industrial run-off or other waste water supplies. A series of cells was produced with varying concentrations of NMP solutions and the power conversions studied by producing a voltage-current plot for each system. The photopotential, photocurrent and power generated by the photogalvanic cell were $0.792 \mathrm{~V}, 27.647 \mu \mathrm{A}$ and $21.89 \mu \mathrm{W}$ respectively. The determined conversion efficiency of cell was determined as $27.305 \%$ and fill factor was 0.242. A mechanism was proposed for the power production process.

\section{References}

Amos, B., Birefringence for factors I: what is birefringence? First published in Stone Chat, the Journal of the UK Facet Cutter's Guild. January-March. Edition, 2005 .37.24.

Andrienko, D., Introduction to liquid crystals. IMPRS school, Bad Marienberg, 2006.

Archer, M., Electrochemical aspects of solar energy conversion. Journal of Applied Electrochemistry, 1975. 5(1): p. 17-38.

Compton, R.G. and C.E. Banks, Understanding voltammetry. 2011: World Scientific.

Crabtree, G., Misewich, J., Ambrosio, R., Clay, K., Integrating renewable electricity on the grid. in AIP Conference Proceedings. 2011. AIP.

De Leon, C.P., Ferrer, A.F., García, J.G., Szánto, D.A.and Walsh, F.C., Redox flow cells for energy conversion. Journal of Power Sources, 2006. 160(1): p. 716-732.

Ermakov, S., Beletskii, A., Eismont, O. and Nikolaev, V., Brief Review of Liquid
Crystals, in Liquid Crystals in Biotribology. 2016, Springer. p. 37-56.

Fromhold, A.T., Quantum mechanics for applied physics and engineering. 2012: Courier Corporation.

Gangotri, K. and V. Indora, Studies in the photogalvanic effect in mixed reductants system for solar energy conversion and storage: Dextrose and Ethylene diaminetetraacetic acid-Azur A system. Solar Energy, 2010. 84(2): p. 271-276.

Halls, J.E. and J.D. Wadhawan, Photogalvanic cells based on lyotropicnanosystems: towards the use of liquid nanotechnology for personalised energy sources. Energy \& Environmental Science, 2012. 5(4): p. 6541-6551.

Halls, J.E., A.A, Altalhi. and F.C.D, Abreu., Concentration-dependent diffusion coefficients of tert-butylferrocene within dodecyltrimethylammonium chloride/brine liquid crystals. Electrochemistry Communications, 2012. 17: p. 41-44.

Halls, J.E., K.J. Wright., J.E. Pickersgill., J.P. Smith. and A. A. Altalhi., Voltammetry within structured liquid nanosystems: Towards the design of a flexible, threedimensional framework for artificial photosystems. Electrochimica Acta, 2012. 70: p. 215-227.

He, Z., Zhong, C., Huang, X., Wong, W.Y., $\mathrm{Wu}, \quad$ H.andCao, Y., Simultaneous enhancement of open-circuit voltage, short-circuit current density, and fill factor in polymer solar cells. Advanced Materials, 2011. 23(40): p. 4636-4643.

Herman, S., Electrical Studies for Trades. 2013: Nelson Education.2

Kato, T., Self-assembly of phase-segregated liquid crystal structures. Science, 2002.2002. 295(5564) p. 2414-2418.

Kounaves, S.P., Voltammetric techniques. 1997, Prentice Hall, Upper Saddle 
River, NJ, USA. p. 709-726.

Pirkl, S. and M. Glogarová, Ferroelectric liquid crystals with high spontaneous polarization. 2011: INTECH Open Access Publisher.

Rolison, D.R., Long, J.W., Lytle, J.C., Fischer, A.E. and Lubers, A.M., Multifunctional 3 D nanoarchitectures for energy storage and conversion. Chemical Society Reviews, 2009. 38(1): p. 226-252.

Rosen, M.J. and J.T. Kunjappu, Surfactants and interfacial phenomena. 2012: John Wiley \& Sons.

Schmidt, H., C. Siedle, and J. Ketterer, DC/AC converter to convert direct electric voltage into alternating voltage or into alternating current. 2006, Google Patents.
Tamhane, K., Formation of lyotropic liquid crystals through the self-assembly of bile acid building blocks. 2009 .

Whitesides, G.M. and B. Grzybowski, Selfassembly at all scales. Science, 2002. 295(5564): p. 2418-2421.

Yano, J. and A. Kitani, Photo-assisted flavin mediated electro-oxidation of NADH model compound using photogalvanic cell. Journal of Electroanalytical Chemistry, 2017.2017. 799: p. 431-435.

Zawodzinski, T., S. Minteer, and G. Brisard, Physical and analytical electrochemistry: The fundamental core of electrochemistry. InterfaceElectrochemical Society, 2006. 15(1): p. 62-65.

\section{How to cite this article:}

Amal A. Altalhi. 2020. Waste water as a Photoelectrochemical Fuel Source for Biphasic Batteries using Liquid Crystals. Int.J.Curr.Microbiol.App.Sci. 9(12): 2252-2258. doi: https://doi.org/10.20546/ijcmas.2020.912.266 